健常高齢者の総合評価における形態，機能，血液諸指標の基準值， および，性差に関する検討

\begin{tabular}{|c|c|c|c|c|c|}
\hline 信孝1) & 島田 & 真澄 ${ }^{1)}$ & 斉藤 & 幸子 1) & 那須美智子 ${ }^{1)}$ \\
\hline & 元 & 泉 1$)$ & 佐藤 & 淳子 1) & るみ11 \\
\hline 倫子 1) & 久代圣 & 登志男 2) & 日野) & 景重明 1) & \\
\hline
\end{tabular}

要 旨 背景：高齢化社会における高齢者の社会的役割は successful aging に代表される方向へ変わ りつつあり，健康評価のあり方も社会的需要に適した基準づくりが求められる。目的：日野原らが提 唱する「新老人運動」の中で，加齢に関する疫学的研究へ自主的に参加した HRV (Health Research Volunteer）の社会的行動，および，疾病の特性についてはすでに報告した。本研究では，これら 70 歳以上の $\mathrm{HRV}$ (男女 319 例 : 平均年齢 $77.9 \pm 4.1$ 歳)について身体の形態と機能の評価を行い, Sackett らの提唱する「文化的健康」を把握するための基準を策定するとともに，性差について検討した。方 法： 2002 年 11 月より 2004 年 3 月の間に, 男性 153 例（平均年齢 $78.3 \pm 4.6$ ，女性 166 例（平均年齢 $77.5 \pm 3.6$ ）について身体計測（身長，体重，BMI，体脂肪指数，非体脂肪係数，四肢周長，骨密度）, 関連する身体機能評価（四肢筋力，歩行速度，安静時代謝率，心脈管機能），血液検查（血球，生化 学, 浸透圧，ホルモン，サイトカイン）を施行した。結果：身体計測值については，男女とも JARD のそれにほほ近似する值を示した。性差に関して，男性は女性より身長，体重が大であったが，体格 指数に差はなかった。男性では非脂肪指数，女性では脂肪指数が有意に大であった。四肢筋は量・質 とも男性で優れ, 歩行速度, 安静時代謝率, 骨密度も男性で有意に高い值を示した。男性では身体計 測値と関連する機能検查值に年齢による差が見られなかったが，女性では身長，体重，非脂肪重量， 下腿周長，握力，歩行時間に年歯差が見られた。基準值は各性別ごとに $20 ， 50,80$ パーセンタイル で表示した。女性では年齢差のある項目についてのみ 80 歳を境に 2 群に分けて示した。結論 : 性差 に関して，男性は骨・筋系にすぐれ，女性では脂肪量が大であった。これらのコホートから身体計測 と機能評価の基準值を求めて示した。

キーワード：健常高齢者, 総合評価, 身体計測, 身体機能, 基準化

\section{I 、はじめに}

高齢者の健康評価は通常の成人のそれとは異な り，単に身体的のみならず心理・精神，そして，社 会的な面からも多様にアプローチすることが必須で ある。そのような見地からすれば，これまで行われ ている通常の老人健診は疾病の早期診断に重点をお くものであり, 高齢者の健康の維持増進の目的に必 ずしも合致するものではない。高齢化した社会の中 で重度の機能跋失に陥ったいわゆる寝たきり老人は

〔論文受付日：2004 年 4 月 16 日〕

1) 財団法人ライフプランニングセンター

2 ) 日本大学医学部駿河台病院循環器内科
数の上ではなお増加しているとしても，今日ではそ れを上回る高齢者人口の増加によって，その率はむ しろ低下しており，健常，または有疾患者であって も重症度の低い高齢者, あるいは, 有疾患者加齢 による心身の機能障害を有する脆弱な高齢者が多く を占めるに至っている11。

日野原らは，増加する高齢者に対して心身共に高 い機能を維持しながら，より活動的，かつ，生産的 に社会的役割を遂行することを目標とする『新老人 (new elder citizens)」なる概念を提唱し，それらの中 で加齢の研究に積極的に参加することを希望するへ ルス・リサーチ・ボランティア（HRV）について社 会行動的特性，および，心血管疾患やそれらに関連 
する危険因子を中心にした身体的特性を明らかにし てきた ${ }^{2,3)}$ 。その結果，このようなコホートでは心 血管疾患の有病率や危険因子の保有率が有意に低 く, したがって, 高齢者の身体的健康状態を評価す る際に，有用な目標となる指標を提供するものと思 われる。

成人の健康評価においては，いわゆる健常集団か ら得られる各指標の平均值 $\pm 2 \mathrm{SD}$ の範囲内を正常域 として定義しているが, 正常の概念について Sacket ら（1997）は，(1)正規分布（ガウス分布，平均的）, (2)パーセンタイル (平均的)，(3)文化的望ましさ（健 康な状態)，(4)危険因子（程度，または，有無），(5) 診断的（標的障害の可能性が高率になる範囲：カッ トオフ值), (6)治療的（措置の必要度を判断する範 囲）などの分類を行っている ${ }^{4)}$ 。新老人コホートの 健康はいわゆる『文化的望ましさ』を表すものであ り, 本研究では高齢者が目指す目標域としての身体 的形態, 機能, および血液諸指標をこのようなコ ホートについて検討したので報告する。

\section{II. 対象と方法}

\section{1. 対象}

『新老人』の会員の中で, 社会健康疫学研究にボラ ンティアとして参加することを希望した HRV 70 〜 94 歳）より文書によるインフォームド・コンセント を得た後, 所定の問診票に従って看護師が直接面接 して調査した。今回の検討は, 2002 年 11 月から 2004 年 3 月までに本調査を受けた 319 例（男性 153 例，平均年齢 $78.3 \pm 4.6$ 歳; 女性 166 例，平均年齢 $77.5 \pm 3.6$ 歳)のデータについて行った(HRV 群)。四 肢の筋力測定は 2003 年 2 月以降の受診者 235 例 (男 性 110 例, 平均年齢 $78.1 \pm 4.6$ 歳; 女性例 125 例, 平均年齢 $77.4 \pm 3.4$ 歳）について行った。

\section{2. 方法}

\section{1）問診情報}

問診票は, 米国の Department of Hdealth \& Human Service が 1995 年に示した老人施設入居の際に 行われる評価マニュアルの中から，外来受診者に対 して必要と考えられる最小必要限の医療情報が簡潔 に得られるよう項目を選んで構造化したものを用い た5)

\section{2）身体情報}

すべての対象者は 13:00〜 15:00の間にライフプ ランニングセンター・クリニックで所定の検査を受
けた。受診に際して飲水, 食事, 服薬には制限を加 えなかったが, 昼食後のカフェインを含む飲料は制 限した。看護師が所定の構造化された質問票に従っ て問診したのち, 以下の検查が行われた：身体計測 (身長, 体重, BMI, 上腕皮脂厚, 上腕周長, 上腿周 長, 下腿周長), 筋力評価 (両側握力, 上肢伸展力, 上肢屈曲力, 下腿伸展力, 下腿屈曲力, 上腿挙上 力), 歩行時間 (5 m 歩行), 血圧, 脈波速度, $\mathrm{ABI}$ (下肢/上肢血圧比), 安静時代謝率, 腰椎骨密度, 血 液検査 (ヘモグロビン, 白血球数, 血液像, 総コレ ステロール, クレアチニン, 尿素窒素 $(\mathrm{BUN}), \mathrm{Na}$, $\mathrm{K}$, 総蛋白, アルブミン, $\mathrm{CRP}$, 血清浸透圧, へモ グロビン A1c, 黄体形成ホルモン (LH), コルチソー ル，遊離テストステロン (TSf), デヒドロエピアン ドロステロンサルフェイト (DHEAS), IL-6, 非顆 粒性白血球数), 尿検査 (定性)。

身体計測の中で, 身長, 体重, 体脂肪率は夕ニ夕 体内脂肪計（TBF-210）を用いて測定した ${ }^{6)}$ 。体脂 肪率より体脂肪重量を算出し，この值を身長 (m) の二乗で除した值を体脂肪指数, また, 同様に非体 脂肪重量を身長 (m) の二乗で除した值を非体脂肪 指数とした。上下肢の周長, 筋囲, 筋面積は所定の 計測法と計算式に従って算出した ${ }^{7)}$ 。握力は hand dynamometer で両側 1 回ずつ測定し, より大きな方 の値を採用した $(\mathrm{kg})$ 。その他の筋力測定には筋力 測定器 GT-300（ISOFORCE）を用い, 訓練された 検查技師 1 名が専任で担当した。筋力は疲労の影響 や測定による障害を避けるため 1 回の測定とし, 等 尺性収縮時における最大值 $(\mathrm{kg} \cdot \mathrm{f})$ で表した。測定 はきき腕, きき足について行った。血圧, 脈波速度, および, ABI の測定には form PWV/ABI（日本コー リン社）を使用し，仰臥位で測定した ${ }^{8)}$ 。骨密度は 腰椎で DEXA 法によって測定した $\left(\mathrm{g} / \mathrm{m}^{2}\right)$ 。骨密度 の標準定量法は日本放射線技術学会基準化検討班の 方法に準じ（学会内資料による），また，評価は日 本骨代謝学会の診断基準 2000 年度改訂版に従って 行った ${ }^{9)}$ 。血液検查は上記の検査項目について行 い, 上腕静脈より $30 \mathrm{~m} l$ 採血した。LH, TSf, DHEAS, コルチソール, IL-6 の測定は BML 社に委 託し, RIA 法で行った。

検查時に骨関節疾患のため歩行検査（男性 3 例, 女性 4 例), 筋力測定が施行できなかった症例（男性 10 例, 女性 17 例), および, 前立腺疾患に対してホ ルモン療法を行っていた症例（男性 6 例）はそれぞ れ関連する検查項目について解析対象から除外し 
た。

\section{3. データの解析}

得られた測定值は Dr. SPSS II（Windows）プログ ラムへ入力して解析の対象とした。すべての值は平 均值 \pm S.D. で表示し, 性に関する群間の平均值 の比較，および，群内の年齢差の検定にはStudent$\mathrm{t}$ 法を用いた。ノンパラメトリックな指標の検定に は $\chi^{2}$ 法を用いた。有意差の限界は両側検定で $p<$ 0.05 とした。評価基準の範囲は 20,50 ，および， 80 パーセンタイルとした ${ }^{10)}$ 。

\section{III. 結 果}

\section{1. 対象者の健康背景}

すでに報告したように ${ }^{3)}$, HRV コホートでは全体 として有病率が低くかったが, 脳血管障害は女性よ り男性で, また, 高コレステロール血症は男性より 女性で有意に高かった（表 1$) 。$

\section{2. 形態指標に見られる性差 (表 2)}

男性は身長，体重において女性より大であるが， BMIには性差を認めなかった。体脂肪指数, 上腕皮 脂厚は女性で, また, 非体脂肪指数は男性で有意に 大であった。四肢の周長は上腕では有意差がなく, 上腿と下腿では男性で有意に大であった。上腕の筋 囲と筋面積では男性が有意に大きな值を示した。腰 椎の骨密度に関しても男性で有意に高值であった。

\section{3. 身体機能に関する性差（表 3)}

男性において握力, 安静時代謝率は有意に大であ り，また， $5 \mathrm{~m}$ 歩行の時間は有意に小であった。上 肢の伸展と屈曲, 下腿の伸展と屈曲, そして, 上腿 の挙上はいずれも男性において有意に大であった。

表 1 対象者の健康背景

\begin{tabular}{lccc}
\hline & 全体 & 男性 & 女性 \\
\hline 症例数 & 319 & 153 & 166 \\
\hline 年齢(歳) & $77.9 \pm 4.1$ & $78.3 \pm 4.6$ & $77.5 \pm 3.4$ \\
脳血管障害 & $304 / 7 / 8$ & $144 / 2 / 7$ & $160 / 5 / 1^{*}$ \\
心筋梗塞 & $315 / 4$ & $150 / 3$ & $166 / 0$ \\
狭心症 & $308 / 11$ & $147 / 6$ & $161 / 5$ \\
高血圧 & $231 / 88$ & $111 / 42$ & $120 / 46$ \\
糖尿病 & $291 / 28$ & $139 / 14$ & $152 / 14$ \\
高コレステロール & $277 / 38$ & $146 / 7$ & $131 / 31^{*}$ \\
血症 & $273 / 25 / 9$ & $122 / 24 / 7$ & $151 / 1 / 2$ \\
喫煙 &
\end{tabular}

脳血管障害については：疾患なし/一過性の虚血/脳梗塞, 契煙については：䒜煙なし/禁煙した/喫煙している，そして， その他の項目については：疾患なし/ありで実数を示した。 *印は有意な性差のあることを示す $\left(\chi^{2}\right.$ 検定による : $\left.p<0.05\right)$

\section{4. 心血管系指標における性差（表 4)}

心拍数，収縮期圧には差がなかったが，拡張期圧 は男性でわずかに高かった。脈波速度には差がな く, ABI は男性で有意に大であった。

\section{5．血液諸指標における性差（表 5)}

ヘモグロビン, クレアチニン, BUN, DHEASは男 性で有意に高く，総コレステロール，Na，LHは女性 で有意に高い值を示した。

\section{6. 年齢差に関する検討（表 6)}

70 歳代と 80 歳以上の 2 群について, それぞれの性 における諸指標の有意差を検定した。

男性に関して有意差を示したのは脈波速度，血清 クレアチニン, BUN, LH, コルチソールで, すべ てが 80 歳代で 70 歳代より有意に高かった（表 6 (a))。女性に関しては, 80 歳代で 70 歳代より身 長, 体重, 非体脂肪重量, 下腿周長, 握力, 血清ア ルブミン值について有意に低く, 総コレステロール と $5 \mathrm{~m}$ 歩行時間は有意に高い值を示した (表 $6(\mathrm{~b}))$ 。

\section{7. 諸測定指標の基準值の設定}

諸測定值の基準値の設定に関して，男性では身体 計測や機能評価において有意な年齢差が認められな かったので, 年齢区分は設けなかった（表 7)。女性

表 2 身体計測值に見られる性差

\begin{tabular}{lrrr}
\hline & $\begin{array}{c}\text { 男性 } \\
(N=153)\end{array}$ & \multicolumn{1}{c}{$\begin{array}{c}\text { 女性 } \\
(N=166)\end{array}$} & $\mathrm{p}$-值 \\
\hline 身長 $(\mathrm{cm})$ & $162.9 \pm 5.2$ & $149.7 \pm 5.5$ & 0.000 \\
体重 $(\mathrm{kg})$ & $60.5 \pm 7.9$ & $50.4 \pm 7.3$ & 0.000 \\
体格指数 & $22.8 \pm 2.7$ & $22.5 \pm 2.9$ & 0.292 \\
脂肪指数 & $3.9 \pm 1.5$ & $6.0 \pm 2.0$ & 0.000 \\
非脂肪指数 & $18.9 \pm 1.7$ & $16.5 \pm 1.2$ & 0.000 \\
皮脂厚 $(\mathrm{mm})$ & $11.1 \pm 3.9$ & $20.4 \pm 6.6$ & 0.000 \\
上腕周長 $(\mathrm{cm})$ & $26.5 \pm 2.4$ & $26.2 \pm 2.7$ & 0.204 \\
上腕笳囲 $(\mathrm{cm})$ & $23.2 \pm 1.9$ & $19.9 \pm 2.1$ & 0.000 \\
上腕筋面積 $(\mathrm{cm})$ & $43.0 \pm 7.4$ & $31.1 \pm 5.5$ & 0.000 \\
上腿周長 $(\mathrm{cm})$ & $39.4 \pm 3.0$ & $37.4 \pm 3.0$ & 0.000 \\
下腿周長 $(\mathrm{cm})$ & $36.2 \pm 2.8$ & $34.0 \pm 2.5$ & 0.000 \\
骨密度 $\left(\mathrm{g} / \mathrm{m}^{2}\right)$ & $1.012 \pm 0.220$ & $0.791 \pm 0.157$ & 0.000 \\
\hline
\end{tabular}

表 3 筋力測定值に見られる性差

\begin{tabular}{crrr}
\hline & \multicolumn{1}{c}{$\begin{array}{c}\text { 男性 } \\
(N=110)\end{array}$} & $\begin{array}{c}\text { 女性 } \\
(N=125)\end{array}$ & $\mathrm{p}$-值 \\
\hline 握力 $(\mathrm{kg}) *$ & $31.4 \pm 5.0$ & $19.8 \pm 3.7$ & 0.000 \\
上腕伸展 $(\mathrm{kg} \cdot \mathrm{f})$ & $9.4 \pm 3.7$ & $7.2 \pm 3.9$ & 0.000 \\
上腕屈曲 $(\mathrm{kg} \cdot \mathrm{f})$ & $17.1 \pm 5.7$ & $11.5 \pm 3.0$ & 0.000 \\
下腿伸展 $(\mathrm{kg} \cdot \mathrm{f})$ & $19.3 \pm 5.2$ & $14.1 \pm 3.3$ & 0.000 \\
下腿屈曲 $(\mathrm{kg} \cdot \mathrm{f})$ & $10.3 \pm 4.1$ & $6.9 \pm 2.4$ & 0.000 \\
上腿挙上 $(\mathrm{kg} \cdot \mathrm{f})$ & $20.3 \pm 5.2$ & \multicolumn{1}{c}{$14.7 \pm 2.9$} & 0.000 \\
\hline \multicolumn{4}{l}{ *握力測定は男性 153 例, 女性 166 例について行われた }
\end{tabular}

(611) 11 
表 4 その他の生理機能に見られる性差

\begin{tabular}{lccc}
\hline & $\begin{array}{c}\text { 男性 } \\
(N=153)\end{array}$ & $\begin{array}{c}\text { 女性 } \\
(N=166)\end{array}$ & $\mathrm{p}$-值 \\
\hline 歩行時間 $(\mathrm{sec} / 5 \mathrm{~m})$ & $2.54 \pm 0.59$ & $2.80 \pm 0.54$ & 0.000 \\
$\mathrm{RMR}(\mathrm{kcal} / \mathrm{min})$ & $1.184 \pm 0.327$ & $0.990 \pm 0.225$ & 0.000 \\
収縮期圧 $(\mathrm{mmHg})$ & $137 \pm 18$ & $135 \pm 19$ & 0.516 \\
拡張期压 $(\mathrm{mmHg})$ & $80 \pm 10$ & $77 \pm 12$ & 0.038 \\
脈圧 $(\mathrm{mmHg})$ & $58 \pm 13$ & $59 \pm 15$ & 0.275 \\
$\mathrm{ABI}$ & $1.170 \pm 0.087$ & $1.129 \pm 0.088$ & 0.000 \\
脈波速度 $(\mathrm{cm} / \mathrm{sec})$ & $1,870 \pm 391$ & $1,863 \pm 355$ & 0.862 \\
心拍数 $(\mathrm{bpm})$ & $68.7 \pm 11.9$ & $71.0 \pm 10.2$ & 0.059 \\
\hline
\end{tabular}

$\mathrm{RMR}$ : resting metabolic rate, $\mathrm{ABI}$ : ankle brachial index

表 5 血液検査に見られる性差

\begin{tabular}{lccc}
\hline & 男性 $(N=153)$ & 女性 $(N=166)$ & $\mathrm{p}$-值 \\
\hline ヘモグロビン $(\mathrm{g} / \mathrm{d} l)$ & $14.1 \pm 1.4$ & $13.1 \pm 1.1$ & 0.000 \\
総コレステロール $(\mathrm{mg} / \mathrm{d} l)$ & $205 \pm 31$ & $229 \pm 47$ & 0.000 \\
クレアチニン $(\mathrm{mg} / \mathrm{d} l)$ & $0.96 \pm 0.22$ & $0.73 \pm 0.18$ & 0.000 \\
$\mathrm{BUN}(\mathrm{mg} / \mathrm{d} l)$ & $19.6 \pm 4.6$ & $18.7 \pm 8.3$ & 0.218 \\
$\mathrm{Na}(\mathrm{mEq} / \mathrm{L})$ & $140.9 \pm 2.1$ & $141.5 \pm 1.7$ & 0.014 \\
$\mathrm{~K}(\mathrm{mEq} / \mathrm{L})$ & $4.1 \pm 0.3$ & $4.1 \pm 0.3$ & 0.497 \\
総蛋白 $(\mathrm{g} / \mathrm{d} l)$ & $7.2 \pm 0.4$ & $7.2 \pm 0.4$ & 0.968 \\
アルブミン $(\mathrm{g} / \mathrm{d} l)$ & $4.2 \pm 0.2$ & $4.2 \pm 0.2$ & 0.403 \\
$\mathrm{CRP}(\mathrm{mg} / \mathrm{d} l)$ & $0.11 \pm 0.21$ & $0.11 \pm 0.27$ & 0.767 \\
ヘモグロビン $\mathrm{A} 1 \mathrm{c}(\%)$ & $5.2 \pm 0.7$ & $5.2 \pm 0.6$ & 0.700 \\
浸透圧 $(\mathrm{mOsm} / \mathrm{L})$ & $290 \pm 5$ & $290 \pm 4$ & 0.710 \\
$\mathrm{LH}(\mathrm{ng} / \mathrm{m} l){ }^{*}$ & $8.8 \pm 7.3$ & $19.8 \pm 8.1$ & 0.000 \\
コルチソール $(\mu \mathrm{g} / \mathrm{d} l)$ & $11.3 \pm 3.9$ & $10.6 \pm 4.2$ & 0.123 \\
遊離テストステロン $(\mathrm{p} / \mathrm{m} l){ }^{*}$ & $7.9 \pm 3.1$ & & \\
$\mathrm{DHEAS}(\mathrm{ng} / \mathrm{m} l)$ & $883 \pm 481$ & $618 \pm 327$ & 0.000 \\
$\mathrm{IL}-6(\mathrm{pg} / \mathrm{m} l)$ & $2.53 \pm 3.87$ & $2.55 \pm 7.15$ & 0.978 \\
リンパ球 $($ 数/ $/ \mu l)$ & $1,715 \pm 486$ & $1,803 \pm 580$ & 0.145 \\
\hline
\end{tabular}

* LH (luteinizing hormone) と遊離テストステロンについては, 前立腺腫瘍に 対する治療を受けている 6 例を除外した。

DHEAS : dehydroepiandrosterone sulfate, BUN : blood urea nirogen, IL-6 : interleukin 6

表 6 測定值に見られる年龃差（有意差のある項目のみを示す）: LH : lueinizing hormone

\begin{tabular}{lccc} 
( $\mathrm{a})$ 男性 & 70 歳代 $(N$ 数 $)$ & 80 歳以上 $(N$ 数 $)$ & $\mathrm{p}$-值 \\
\hline 脈波速度 $(\mathrm{cm} / \mathrm{sec})$ & $1,800 \pm 327(107)$ & $2,034 \pm 473(46)$ & 0.001 \\
クレアチニン $(\mathrm{mg} / \mathrm{d} l)$ & $0.93 \pm 0.21(107)$ & $1.02 \pm 0.22(46)$ & 0.020 \\
尿素窒素 $(\mathrm{mg} / \mathrm{d} l)$ & $19.1 \pm 4.5(107)$ & $20.8 \pm 4.7(46)$ & 0.032 \\
$\mathrm{LH}(\mathrm{ng} / \mathrm{m} l)$ & $7.9 \pm 6.2(102)$ & $10.8 \pm 9.2(45)$ & 0.024 \\
コルチソール $(\mu \mathrm{g} / \mathrm{d} l)$ & $10.9 \pm 3.6(107)$ & $12.4 \pm 4.4(46)$ & 0.031 \\
\hline$(\mathrm{b})$ 女性 & 70 歳代 $(N$ 数) & 80 歳以上 $(N$ 数 $)$ & $\mathrm{p}$-值 \\
\hline 身長 $(\mathrm{cm})$ & $150.6 \pm 75.7(118)$ & $147.4 \pm 4.2(48)$ & 0.001 \\
体重 $(\mathrm{kg})$ & $51.2 \pm 7.4(118)$ & $48.3 \pm 6.5(48)$ & 0.018 \\
非脂肪重量 $(\mathrm{kg})$ & $50.4 \pm 5.2(106)$ & $49.4 \pm 5.9(45)$ & 0.004 \\
下腿周長 $(\mathrm{cm})$ & $34.3 \pm 2.6(118)$ & $33.2 \pm 2.3(48)$ & 0.019 \\
握カ $(\mathrm{kg})$ & $20.3 \pm 3.8(118)$ & $18.7 \pm 3.2(48)$ & 0.011 \\
歩行時間 $(\mathrm{sec} / 5 \mathrm{~m})$ & $2.68 \pm 0.46(115)$ & $3.09 \pm 0.60(47)$ & 0.000 \\
総コレステロール $(\mathrm{mg} / \mathrm{d} l)$ & $224 \pm 32(118)$ & $242 \pm 71(48)$ & 0.019 \\
血清アルブミン $(\mathrm{g} / \mathrm{d} l)$ & $4.2 \pm 0.2(118)$ & $4.1 \pm 0.3(48)$ & 0.034 \\
\hline
\end{tabular}


表 7 身体計測と機能評価における目標值について（パーセンタイル表示）

\begin{tabular}{|c|c|c|c|c|c|c|}
\hline \multirow{2}{*}{ パーセンタイル } & \multicolumn{3}{|c|}{ 男 性 } & \multicolumn{3}{|c|}{ 女 性 } \\
\hline & 20 & 50 & 80 & 20 & 50 & 80 \\
\hline 身長 $(\mathrm{cm})^{* *}$ & 158.7 & 162.8 & 166.8 & 144.9 & 149.9 & 154.0 \\
\hline 体重 $(\mathrm{kg}) * *$ & 54.0 & 60.6 & 67.0 & 43.8 & 50.4 & 56.1 \\
\hline 体格指数 & 20.6 & 22.9 & 24.9 & 19.8 & 22.2 & 25.0 \\
\hline 体脂肪重量（kg） & 6.8 & 10.1 & 13.9 & 9.5 & 13.0 & 16.8 \\
\hline 非体脂肪重量 $(\mathrm{kg}) * *$ & 45.9 & 49.8 & 54.8 & 33.8 & 37.2 & 39.8 \\
\hline 上腕皮脂厚（mm） & 8 & 11 & 14 & 14 & 20 & 26 \\
\hline 上腕周長（cm） & 24.4 & 26.6 & 28.2 & 24.0 & 26.1 & 28.3 \\
\hline 上腕筋囲（cm） & 21.6 & 23.2 & 24.6 & 18.3 & 19.5 & 21.2 \\
\hline 上腕筋面積 $\left(\mathrm{cm}^{2}\right)$ & 37.0 & 42.3 & 48.0 & 26.4 & 30.0 & 35.4 \\
\hline 上腿周長（cm） & 36.8 & 39.3 & 41.6 & 34.9 & 37.3 & 40.1 \\
\hline 下腿周長 $(\mathrm{cm}) * *$ & 34.0 & 36.0 & 38.6 & 31.7 & 33.9 & 36.3 \\
\hline 握力 $(\mathrm{kg}) * *$ & 27.4 & 31.7 & 36.0 & 16.4 & 20.0 & 23.0 \\
\hline 上腕伸展 $(\mathrm{kg} \cdot \mathrm{f})$ & 6.8 & 8.7 & 11.1 & 5.3 & 6.7 & 8.2 \\
\hline 上腕屈曲 $(\mathrm{kg} \cdot \mathrm{f})$ & 13.4 & 16.3 & 20.4 & 9.3 & 11.1 & 13.9 \\
\hline 下腿伸展（kg・f） & 14.9 & 18.5 & 22.9 & 11.5 & 14.5 & 16.9 \\
\hline 下腿屈曲（kg・f） & 7.8 & 9.5 & 12.2 & 5.3 & 6.6 & 8.1 \\
\hline 上腿挙上（kg・f） & 16.2 & 19.7 & 24.2 & 12.9 & 14.7 & 17.0 \\
\hline 歩行時間 $(\mathrm{sec} / 5 \mathrm{~m}) * *$ & 2.16 & 2.44 & 2.84 & 2.34 & 2.75 & 3.18 \\
\hline $\operatorname{RMR}(\mathrm{kcal} / \mathrm{min})^{*}$ & 0.900 & 1.180 & 1.392 & 0.830 & 0.950 & 1.130 \\
\hline
\end{tabular}

* RMR : resting metabolic rate

**女性については年齢別の目標値を表 8 に示す

表 8 女性における身体計測と機能評価における年齢別目標値について（パーセン タイル表示)

\begin{tabular}{|c|c|c|c|c|c|c|}
\hline \multirow{2}{*}{ パーセンタイル } & \multicolumn{3}{|c|}{70 歳代 } & \multicolumn{3}{|c|}{80 歳以上 } \\
\hline & 20 & 50 & 80 & 20 & 50 & 80 \\
\hline 身長（cm） & 146.2 & 151.1 & 155.0 & 143.5 & 147.1 & 151.6 \\
\hline 体重（kg） & 44.4 & 51.5 & 57.0 & 42.3 & 48.1 & 53.1 \\
\hline 非体脂肪重量（kg） & 34.3 & 37.6 & 40.2 & 33.2 & 35.7 & 38.6 \\
\hline 下腿周長（cm） & 32.1 & 34.2 & 36.7 & 31.2 & 33.3 & 34.9 \\
\hline 握力（kg） & 16.6 & 20.3 & 23.3 & 16.0 & 18.4 & 21.8 \\
\hline 歩行時間（sec/5 m） & 2.23 & 2.67 & 3.06 & 2.66 & 3.01 & 3.39 \\
\hline
\end{tabular}

に関しては年齢区分のない基準値の他に（表 7)，身 長，体重，非体脂肪重量，握力，歩行時間について は, 別途 70 歳代と 80 歳以上の 2 群に分けて示した (表 8)。評価基準はそれぞれ 20，50，そして，80 パーセンタイル值で表した。

\section{IV. 考察}

これまでのいわゆる総合的な健診の死亡率や罹病 率対する有用性につては十分なエビデンスが得られ ていない11)。しかし，男性であれば前立腺や大腸， 女性であれば乳房の悪性腫瘍といった標的疾患に対 するスクリーニング的な評価に有用性が認められて いるとすれば，高齢者の健康評価にも同様な戦略が 求められ, したがって, 標的に焦点を合わせた包括
的なアプローチが必要と考えられる。高齢者の健康 の維持・増進において疾病の早期の診断や治療も重 要であるが，加齢に伴う心身の機能障害の予防的対 応も同様に重視されなければならない。

Fried らは高齢者の加齢に伴う機能障害を臨床的 な実在，すなわち frailty として捉える試みを提案し ている ${ }^{10)}$ 。そこでは, (1)体重の減少, (2)筋肉減少症, (3)筋力低下, (4)歩行速度の低下, (5)持久力の低下, (6)活動性の低下の 6 項目を主要な徵候として捉え, これらのうち 3 項目以上を満たすものを frailty 陽性 (positive)，0 項目であれば陰性 (negative)，そして, それ以外を中間（intermediate）と分類し， 7 年間の 前向き研究によってこれらの分類が死亡率に関する リスク層別化に有用であることを示した。Frailtyの 発症頻度は男性で $4 \%$, そして, 女性で $8 \%$ と後者に 
頻度の高いことが示唆されており ${ }^{12)}$, それらの早期 診断と介入による予防効果が期待されている ${ }^{13)}$ 。

Frailty 特徵づける主な要因は筋肉減少症, 栄養 障害，そして，それらに伴う身体機能の低下であり， 身体計測（anthropometry）はそのような意味で高 齢者にとって重要な健康情報となるが，その評価に おいては基準，あるいは，目標となる指標が必要で ある。従来, 成人の健康評価における基準はいわゆ る健常成人の平均值をもとに決められているが, 高 齢者の健康にはそれ以外の要因も考慮すべきと考え られる。すなわち, 健康に関する Sacket らの定義の 中で, 高齢者の場合には『文化的望ましさ』として 健康状態を表すことが最も適切と思われ，評価の基 準を successful aging で象徵される, (1)少ない疾病, (2)高い心身の機能，そして，(3)深い社会的まじわり を維持しながら生活しているコホートに求めること の妥当性が理解される ${ }^{4)}$ 。本研究の対象となったコ ホートの社会的行動特性と疾病状態の特性について はすでに報告したが2,3), 今回はこれらの対象者に ついて加齢に伴う身体的変化を形態と機能の面より 評価した。

我が国における身体計測の基準值は自立している 健常者について得られたデータに基づいて JARD (Japanese Anthropometric Reference Data 2001) に 示されており ${ }^{7)}$, 対象項目は身長, 体重, BMI, 上 腕周長，下腿周長，上腕三頭筋皮下脂肪厚，肩胛骨 下部脂肪厚, 上腕筋囲, 上腕筋面積であるが, 本研 究では anthropometry に関しては肩胛骨下部脂肪厚 を除く他のすべての項目について，同様の方法に よって評価した。その他, 機能の面では frailty の評 価に関連のある筋力, 歩行速度, 安静時代謝率, 心 脈管機能, ホルモン, サイトカイン, 骨密度につい ても検討した。

健康に関する性差の研究は有病率や死亡率につい て多く見られ，いずれも男性が短命であり，かつ生 存中も男性の健康状態は女性よりも医学的に見て劣 ると考えられているが, 心理・社会的な面も含めれ ば女性の愁訴は男性より多く，かつ，受診率や受療 率も女性の方が多いとされている ${ }^{14)}$ 。本研究では高 齢に至るまで比較的良好な健康状態を維持し， か つ, 社会的に活動的で生産的な生活を続けている特 殊なコホートを検討の対象としたが，このような集 団に見られる身体情報は生物医学的にも意義あるも のと思われる。

Anthropometry に関して JARD のデータと比較す
ると, HRV コホートはほぼそれに近似する結果を示 した。しかし, 男女とも身長, 体重, BMI, 上腕周 長, 下腿周長, 上腕三頭筋皮下脂肪厚で高い傾向を 示し, これに対して上腕筋囲, 上腕筋面積はほほ同 等であったことから, 本研究の対象者は全体として 男女とも脂肪量が多いと考えられる。特にこのよう な傾向は 80 歳以上で顕著であった。また, 本研究の 対象者の身長は男女とも台湾人のデー夕にほぼ匹敵 するくらい高身長であるが ${ }^{15)}, \mathrm{BMI}$ は後者で著しく 大であり，形態的には明らかに異なっている。しか し, 高齢者の身長は加齢による短縮が加わるので正 確には測定できないとされており ${ }^{16)}$ ，したがって， 本研究の対象者の身長が高いのは生来のものか, 脊 柱の変形や短縮の影響が少ないためかどうかは不明 である。

本研究では70歳以上を対象としているが, 年齢の 差を 70 歳代と 80 歳以上とで比較すると, 男性では anthropometric な指標に有意差はなく, 脈波速度, 血清クレアチニン, BUN がより高齢群で高くなっ ていることは動脈系の加龃による変化を示唆するも のと思われる。LH が高年群で有意に高いことも加 齢に関連する変化と推測されるが ${ }^{12)}$, コルチソール については今後の検討が必要である。女性では身 長, 体重, 下腿周長, 握力, 歩行速度の減少は加齢 に伴う形態と機能の変化を表すと思われるが, 尿素 窒素, 血清 $\mathrm{Na}$, 総コレステロールの年齢差の機序は 不明である。

性差に関しては男性が女性より形態が大であり, 身体の組成に関しては単純化して Siri の 2 分画モデ ルを適用するならば ${ }^{17)}$, 男性では非体脂肪指数, そ して, 女性では体脂肪指数が有意に高い。非体脂肪 分画は主として水分, 鉱質, 蛋白からなり ${ }^{18)}$, 血清 浸透圧に性差が見られなかったことより，水バラン スに差異がないとすれば，鉱質と蛋白の重量は男性 で有意に高く, かつ, 蛋白の主要部分を占める筋に 関しては, 等尺性筋収縮力が四肢筋のいずれの測定 值においても男性で有意に大であったことは, 量質 とも男性において優れていることを示唆している。 このことは, 歩行速度, 安静時代謝率, 血清クレア チニン, BUNが男性において有意に女性より高值 であることによっても支持される。性ホルモンに関 しては DHEAS が男性で, また, LH は女性で有意に 高值であった。

Frailty と既存の疾病との関連は広く検討されてい るが, 併存する種々の疾患と直接の関連がないとさ 
れているなかで，心不全や虚血性心疾患とは有意な 相関が示唆されていることから ${ }^{19,20)}$, 本研究では心 拍数, 血圧（収縮期圧, 拡張期圧, 脈圧), $\mathrm{ABI}$, 脈 波速度を関連する指標として取り上げた。これらの 項目に関する年齢差は脈波速度のみ男性で 80 歳以 上が70歳代より高值を示したが, その他の指標には 有意差が見られなかった。性差については拡張期圧 と $\mathrm{ABI}$ に有意差を認めたが, 機能としてどのような 意味があるかは不明であり，また，臨床的に意味の ある差であるとは考えにくい。

身体計測やそれらに関連する機能評価においては 基準となるスケールが必要であるが，本研究では主 として frailty の評価に必須と思われる項目に焦点を 絞り, HRV として研究に協力の得られたコホートに ついて基準となるスケールの作成を試みた。JARD では平均值, 中央值, そして, 細分化されたパーセ ンタイル区分が用いられているが7)，本研究では実 利的な目的から $20,50,80$ パーセンタイル区分にと どめた。Fried らは Frailty の評価において機能低下 を健常コホートの 20 パーセンタイル以下としてい る。このレベルは経験的に決められたものではある が，とりあえずの指標としては妥当なレベルと考え られる。しかし，その正当性に関しては今後さらに 検討が必要と思われる。身体計測の形態と機能につ いて，男性では年齢差が見られないが，女性では加 齢によって低下が見られる項目があるので，それら ついては 80 歳を境に年齢別の評価をすることが必 要と考えられる。

高齢者の健康評価は併存病の有無やそれらの重症 度のみならず，加齢に伴う形態や機能の評価も同様 に重要であり，そのような観点からすれば frailtyの 概念は問題指向型であり，問題解決への有力な戦略 になり得ると思われる。本研究の対象群は HRV と して参加した心身機能が高く，かつ社会的な交流を 積極的に続けているコホートであり，一般にいう平 均的な高齢者を意味するものではない。高齢化した 社会における高齢者の役割が変わっていく時代にお いて，高齢者の身体評価に新たな目標となる基準值 を設定することは社会の需要に適合するものと思わ れる。

\section{文 献}

2）道場信孝, 平野真澄，松原博義，日野原重明，佐伯圭一 郎, 西山悦子, 高木廣文, 柳井晴夫：LPC 式生活習慣検 査による「新老人」の行動特性に関する研究. 日本医事 新報 4149: 26-32, 2003

3）道場信孝，佐藤淳子，平野真澄，石清水由紀子，鶴若麻 理, 松原博義, 久代登志男, 日野原重明: ライフプラン ニングセンターに扔ける「新老人』の身体的健康特性に 関する検討 : 第 5 次循環器疾患基礎調查（2000）との比 較をもとにして。総合健診（in press）

4) Sackett DL, Richardson WS, Rosenberg W \& Haynes RB : Evidence-based Medicine : How to Practice \& Teach EBM. Churchill Livingstone, New York, 1997

5) Morris JN, Murphy K, Nonemaker S : Long Term Care Resident Assessment Instrument User's Manual Version 2.0. Baltimore, HCFA, 1995

6）佐藤富夫：電気伝導法，インピーダンス法. 日本臨床 53 ： 179-182, 1995

7) JARD2001:日本人の新身体計測值. 栄養評価と治療, メ デイカルレビュー社 19:8-81, 2002

8) Tomiyama H, Yamashina A, Arai T, Hirose K, Chikamori T, Hori S, Doba N, Hinohara S : Influences of Age and Gender on Results of Noninvasive Brachial-ankle Pulse Wave Velocity Measurement-A Survey of 12517 Subjects. Atherosclerosis $166: 303-309,2003$

9）折茂肇：原発性骨粗䯻症の診断基準一 2000 年度改訂版 (概要) Osteoporosis Japan 9:9-17, 2001

10) Fried LP, Tangen CM, Walston J, Newman AB, Hirsch $C$, Gottdiener J, et al. : Frailty in Older Adults : Evidence for a Phenotype. J Gerontol A Biol Sci Med Sci 56 : M14656,2001

11）矢野栄二: 産業保健活動の健康影響指標に関する研究一 $\mathrm{EBM}$ 健康診断一. 平成 14 年度厚生労働科学研究費補助 金（労㗢衛生総合研究事業和田班）分担研, 2003

12) Walston JW \& Fried LP : Frailty and the Older Man. Med Clincs North Am 83 : 1173-1194, 1999

13) Buchner DV \& Wagner EH : Preventing Frail Health. Health Prom Dis Prev $8: 1-17,1992$

14) Wingard DL: The Sex Differential in Morbidity, Mortality, and Lifestyle. Ann Rev Public Health $5:$ 433-458, 1984

15) Chiu H-C, Chang H-Y, Mau L-W, Lee T-K \& Liu H-W : Height, Weight, and Body Mass Index of Elderly Persons in Taiwan. G Gelontol 55A : M684-M690, 2000

16) Prissinotte E, Pisent C, Sergi G, Grioletto F \& Enzi G : Anthropometric Measurements in the Elderly : Age and Gender Differences. Brit J Nutr 87 : 177-186, 2002

17) Siri WE : Body Composition from Fluid Spaces and Density Analysis of Methods. In : Brozek J, Henschel A, eds. Techniques for Measuring Body Composition. Washington DC : National Academy of Sciences, 1961

18) Chumlea WC, Baumgartner RN \& Vellas BP : Anthropometry and Body Composition in the Perspective of Nutritional Status in the Elderly. Nutrition $7: 57-60,1991$

19) McGann PE : Comorbidity in Heart Failure in the Elderly. Clin Geriatr Med $16: 631-648,2000$

20) Newman AB, Gottdiener JS, McBurnie MA, Hirsch GH, Kop WJ, Tracy R, et al. : Association of Subclinical Cardiovascular Disease with Frailty. J Geront 56 : M158M166, 2001

1）原田泰：人口減少の経済学，PHP，東京，2001 


\title{
Studies on the Standardization and Gender Differences of Anthropometry, Selected Physical Functions and Several Blood Parameters Derived from the Healthy Elderly Cohort in Comprehensive Health Evaluation
}

\author{
Nobutaka Doba, Masumi Shimada, Sachiko Sarto, Michiko Nasu, Akiko Kuratsuj, Izumi Motoda \\ Junko Sato, Narumi KaI, Michiko Mryazaki, Toshio Kushiro, Shigeaki Hinohara
}

Social roles of the elderly have been changing in the era of an aging society and been represented by the term of successful aging. The cohort of health research volunteers (HRV) in the new elder citizens proposed by the Life Planning Center has been studied on their sociovihavioral and disease related aspects, of which characteristics have already been described elsewhere. Since HRV cohort has been defined as culturally desirable normal after the concept by Sackett, the present study was carried out to establish standardization of anthropometric and selected physical functional measurement values along with the exploration of gender differences. Subjects consisted of 153 males $(78.3 \pm 4.6 \mathrm{y} / \mathrm{o})$ and 166 females $(77.5 \pm 3.6 \mathrm{y} / \mathrm{o})$, to whom following parameters were examined ; height, weight, BMI, fat index, non-fat index, extremity circumferences, upper arm muscular area, bone mineral density (BMD), muscular strength of the extremities, walking speed, resting metabolic rate (RMR), cardiovascular functions, hematology and selected blood chemistries. Comparing to Japan Anthropometric Reference Data (JARD), both genders of HRV showed almost similar results to those of JARD with minor variations. Concerning gender differences within HRV, the male was characterized with larger muscular volume and its higher quality along with faster walking speed, higher RMR and BMD than those of the female. While age differences were not observed in any anthropometric and related functional measurements of the male, the female revealed significant age related differences in height, weight, non-fat weight, grip strength and walking speed. Therefore, standard values in terms of 20 , 50 and 80 percentiles were derived in both genders based on these data, and only above mentioned selected parameters showing age related differences in the female were specified with the age above and below 80 years.

Key Words : Healthy Elderly, Comprehensive Evaluation, Anthropometry, Physical Function, Standardization 